\title{
Advances in 5-Aminolevulinic Acid Priming to Enhance Plant Tolerance to Abiotic Stress
}

\author{
Shuya Tan, Jie Cao, Xinli Xia (1) and Zhonghai Li *
}

check for updates

Citation: Tan, S.; Cao, J.; Xia, X.; Li, Z. Advances in 5-Aminolevulinic Acid Priming to Enhance Plant Tolerance to Abiotic Stress. Int. J. Mol. Sci. 2022, 23, 702. https://doi.org/10.3390/ ijms23020702

Academic Editors: Lam-Son Phan Tran and Manish Kumar Patel

Received: 13 October 2021

Accepted: 5 January 2022

Published: 9 January 2022

Publisher's Note: MDPI stays neutral with regard to jurisdictional claims in published maps and institutional affiliations.

Copyright: (C) 2022 by the authors. Licensee MDPI, Basel, Switzerland. This article is an open access article distributed under the terms and conditions of the Creative Commons Attribution (CC BY) license (https:// creativecommons.org/licenses/by/ $4.0 /)$.
National Engineering Laboratory for Tree Breeding, College of Biological Sciences and Technology, Beijing Forestry University, Beijing 100083, China; tsy20@bjfu.edu.cn (S.T.); CaoJie@bjfu.edu.cn (J.C.); xiaxl@bjfu.edu.cn (X.X.)

* Correspondence: lizhonghai@bjfu.edu.cn

\begin{abstract}
Priming is an adaptive strategy that improves plant defenses against biotic and abiotic stresses. Stimuli from chemicals, abiotic cues, and pathogens can trigger the establishment of priming state. Priming with 5-aminolevulinic acid (ALA), a potential plant growth regulator, can enhance plant tolerance to the subsequent abiotic stresses, including salinity, drought, heat, cold, and UV-B. However, the molecular mechanisms underlying the remarkable effects of ALA priming on plant physiology remain to be elucidated. Here, we summarize recent progress made in the stress tolerance conferred by ALA priming in plants and provide the underlying molecular and physiology mechanisms of this phenomenon. Priming with ALA results in changes at the physiological, transcriptional, metabolic, and epigenetic levels, and enhances photosynthesis and antioxidant capacity, as well as nitrogen assimilation, which in turn increases the resistance of abiotic stresses. However, the signaling pathway of ALA, including receptors as well as key components, is currently unknown, which hinders the deeper understanding of the defense priming caused by ALA. In the future, there is an urgent need to reveal the molecular mechanisms by which ALA regulates plant development and enhances plant defense with the help of forward genetics, multi-omics technologies, as well as genome editing technology.
\end{abstract}

Keywords: 5-ALA; defense priming; abiotic stress; multi-omics; plant hormone

\section{Introduction}

Defense priming refers to a physiological state (a state of readiness for defense) that is induced after the plants perceive a variety of stimuli, such as pathogens, arthropods, and abiotic cues, as well as chemicals (Figure 1). In this state, the defense responses are deployed in a faster, stronger, and/or more sustained manner, thus defense priming is considered an adaptive and low-cost defensive strategy [1]. The pathogen produces molecules with different biochemical natures (peptides, polysaccharides, or lipids) that are sensed by plants through the corresponding receptors, thus inducing plant priming [2] The common bean (Phaseolus vulgaris) activates enhanced plant defense by inoculation with Rhizobium etli and develops stronger resistance to Pseudomonas syringae compared with unstimulated plants [3]. Herbivore-inducible plant volatiles (HIPVs) released in response to herbivore attack can induce priming in neighboring plants, which exhibit faster or stronger defense activation and insect resistance when subjected to insect feeding [4]. Repeated exposure of plants to mild abiotic signals, such as heat, cold, or salt, can also trigger plants into a defense priming state [5]. In addition, pretreatment with low concentrations of chemicals such as hydrogen peroxide $\left(\mathrm{H}_{2} \mathrm{O}_{2}\right)$, sodium hydrosulfide (NaHS), sodium chloride $(\mathrm{NaCl})$, sodium nitroprusside (SNP), $\gamma$-aminobutyric acid (GABA), melatonin, polyamines (PAs), as well as 5-aminolevulinic acid (ALA) also induces plants into defense priming status [6-8], in which plants respond to biological and abiotic stresses through faster and stronger defensive activation [9]. Furthermore, the ability of priming to enhance stress tolerance can be self-propagating. For example, defense priming occurs in roots, 
while transcriptional differences can be detected in both roots and leaves [10]; mobile wound signals transmitted from local damaged sites to distal undamaged sites induce the whole plant into priming [11]; infestation of plants with phloem-feeding whitefly (Bemisia tabaci) triggers local and systemic defense priming [12]. Interestingly, the priming status of plants can be inherited across generations. For example, a transgenerational priming response against pathogen attack can last for at least two generations in common beans upon treatment with the priming agent GABA [13]. This transgenerational inheritance of defense priming may involve epigenetic regulation $[2,14]$.

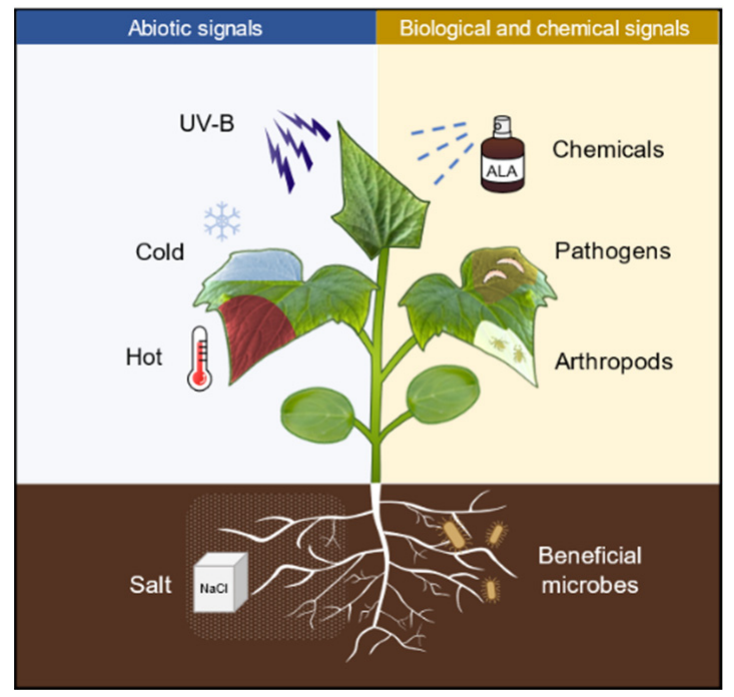

Figure 1. Numerous biotic and abiotic stress as well as defense-related chemicals are capable of inducing plants into priming status. UV-B, ultraviolet B (UVB); ALA, 5-aminolevulinic acid; $\mathrm{NaCl}$, sodium chloride.

\section{Biosynthesis of 5-Aminolevulinic Acid}

5-Aminolevulinic acid (ALA) has been found to increase tolerance to various stresses and is a promising chemical molecule for application in agriculture. ALA is widely found in various living organisms, including bacteria, algae, plants, and animals, and is a universal precursor for the synthesis of all tetrapyrroles (chlorophyll, heme, siroheme, vitamin $\mathrm{B}_{12}$, and phytochromobilin) $[15,16]$. Therefore, to better understand the biological role of ALA and underlying molecular mechanisms in defense priming, we firstly made a brief introduction to its biosynthesis (Figure 2). There are two pathways for the biosynthesis of ALA, the $C_{4}$ pathway (or Shemin pathway) and the $C_{5}$ pathway (or Beale pathway) [17]. The $\mathrm{C}_{4}$ pathway is found in animals, fungi, and some algae and bacteria. In this pathway, ALA is produced by direct condensation of succinyl-CoA and Gly catalyzed by ALA synthase. The $C_{5}$ pathway is mainly found in plants and archaea, which consists of a

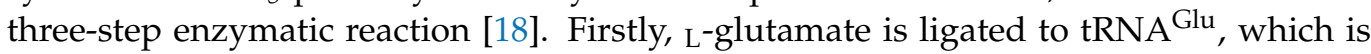
catalyzed by glutamyl-tRNA synthetase (GluTS) to form ${ }_{\text {- }}$ glutamy-tRNA. Secondly, the carboxyl group of Glu-tRNA is reduced to a formyl group and ${ }_{\mathrm{L}}$-Glu-tRNA is converted

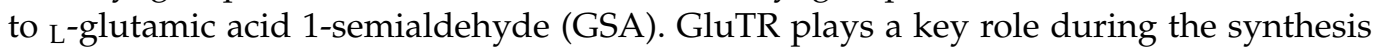
pathway of ALA. Lastly, GSA undergoes an isomerization reaction catalyzed by glutamate1-semialdehyde aminotransferase (GSAT) to form ALA. These reactions are located in the chloroplast stroma [19]. 


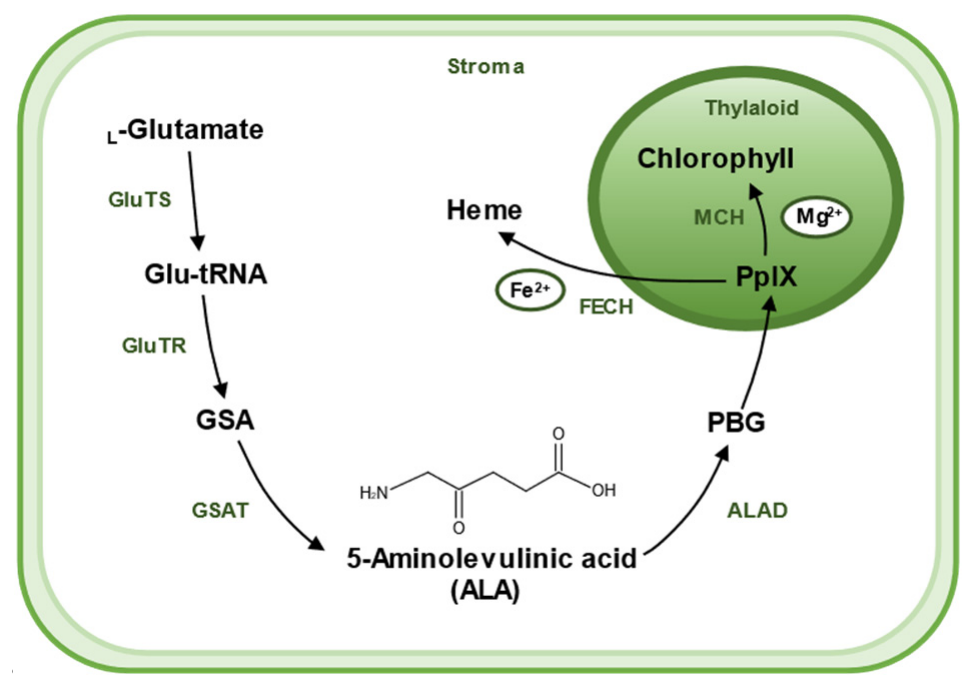

Figure 2. A sketch shows the biosynthetic pathway of ALA and the use of ALA as a substrate for the synthesis of chlorophyll and heme in plants. ALA is created in stroma of chloroplast. The main biosynthetic pathway of ALA is the Beal pathway, which starts from glutamic acid. L-Glutamate is

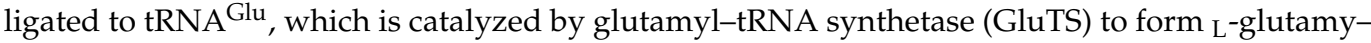
tRNA. Then, Glu-tRNA is converted to L-glutamic acid 1-semialdehyde (GSA), a reaction catalyzed by the key rate-limiting enzyme glutamyl-tRNA reductase (GluTR). GSA then undergoes an isomerization reaction catalyzed by glutamate-1-semialdehyde aminotransferase (GSAT) to form ALA. Two molecules of ALA are catalyzed by ALA dehydratase (ALAD) and agglomerate to form a pyrrole ring called porphobilinogen (PBG). Then, after a six-step enzymatic reaction, four molecules of PBG polymerize to form a porphyrin structure, eventually forming (PpIX). PpIX combines with different enzymes and substrates to yield different products; PpIX chelates $\mathrm{Fe}^{2+}$ with Ferrochelatase (FECH) to produce heme, and $\mathrm{Mg}^{2+}$ with $\mathrm{Mg}$-chelatase $(\mathrm{MCH})$, and then undergoes a series of catalytic reactions to produce chlorophyll.

Chlorophyll and heme, with ALA as their precursors, are involved in many biochemical processes. They share a series of steps in the synthesis pathway from ALA to protoporphyrin IX (PpIX). It starts with two molecules of ALA catalyzed by ALA dehydratase (ALAD), which aggregates to form a pyrrole ring called porphobilinogen (PBG); this is followed by a six-step enzymatic reaction in which four molecules of PBG polymerize to form a porphyrin structure, eventually forming PpIX. The synthetic pathway branches off here to produce heme or chlorophyll, respectively. PpIX chelates $\mathrm{Fe}^{2+}$ by Ferrochelatase $(\mathrm{FECH})$ to produce heme or chelates $\mathrm{Mg}^{2+}$ by $\mathrm{Mg}$-chelatase $(\mathrm{MCH})$ and undergoes a series of catalytic reactions to produce chlorophyll. ALA was originally obtained by chemical methods, which is a complex process and difficult to purify, resulting in a low yield and high price [20]. At present, ALA can be produced commercially through easier, cheaper, and sustainable microbial methods [21-23].

\section{ALA Priming Enhances Plant Resistance to Abiotic Stresses}

Abiotic stresses are considered to be major environmental factors limiting the yield and quality of crop plants. Developing effective strategies to mitigate the deleterious effects of abiotic stresses is critical for sustainable agriculture and food security. Recent studies have shown that exogenous treatment of plants with 5-ALA can enhance abiotic stress tolerance by inducing molecular and physiological defense mechanisms, providing a promising strategy for mitigating abiotic stress in plants. Here, we focus on reviewing the physiological and molecular mechanisms of action of ALA priming in alleviating salt stress, extreme temperature stress, drought stress, and UV stress, and construct a regulatory network to show them systematically (Figure 3; Table 1). 


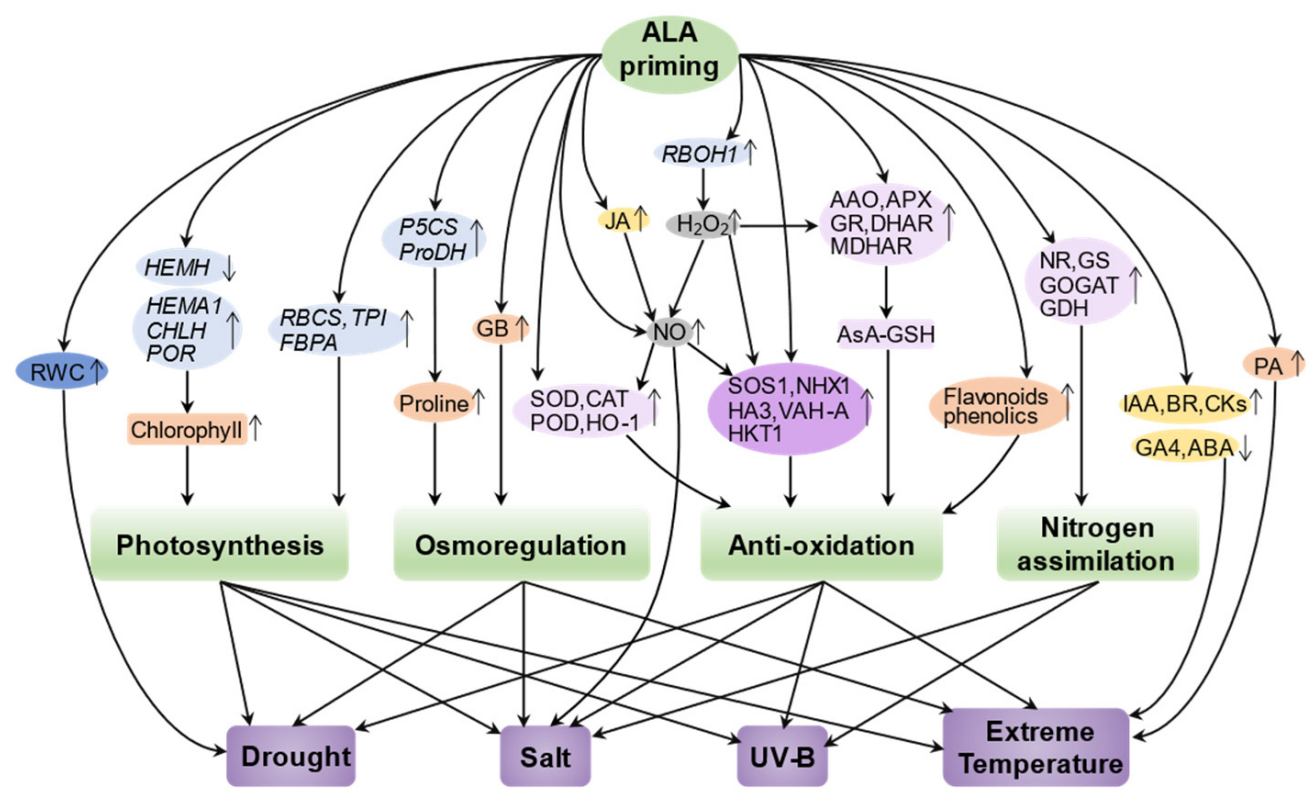

Figure 3. Construction of a regulatory network of ALA priming-mediated abiotic stress tolerance. Priming with ALA enhances the ability of plants to cope with various stresses such as drought stress, salt stress, UV-B stress, and extreme temperature stress by regulating photosynthesis, osmoregulation, antioxidant capacity, and nitrogen assimilation in plants through finely tuning the activities of enzymes (light violet), channel proteins (dark violet), hormones (yellow), signaling molecules (gray), small organic molecules (orange), gene expression (light blue), or physiological levels (dark blue). The upward and downward arrows represent an upregulation or downregulation, respectively. HEMA1, glutamyl-tRNA reductase; CHLH, Mg-chelatase; POR, protochlorophyllide oxidoreductase; NR, nitrate reductase; NiR, nitrite reductase; GS, glutamine synthetase; GOGAT, glutamate synthase; CAT, catalase; SOD, superoxide dismutase; APX, ascorbate peroxidase; GR, glutathione reductase; RWC, relative water content; GDH, glutamate dehydrogenase; P5CS, delta-1-pyrroline-5-carboxylate synthase; $\mathrm{HKT1}$, $\mathrm{K}^{+}$transporter protein 1 ; $\mathrm{NHX1}, \mathrm{Na}^{+} / \mathrm{H}^{+}$antiporter; VHA-A, proton pump; GB, glycine betaine; DHAR, dehydroascorbic acid reductase; MDHAR, monodehydroascorbic acid reductase; AsA-GSH, ascorbate-glutathione cycle. 
Table 1. Effects of ALA priming on the tolerance to environmental stressors.

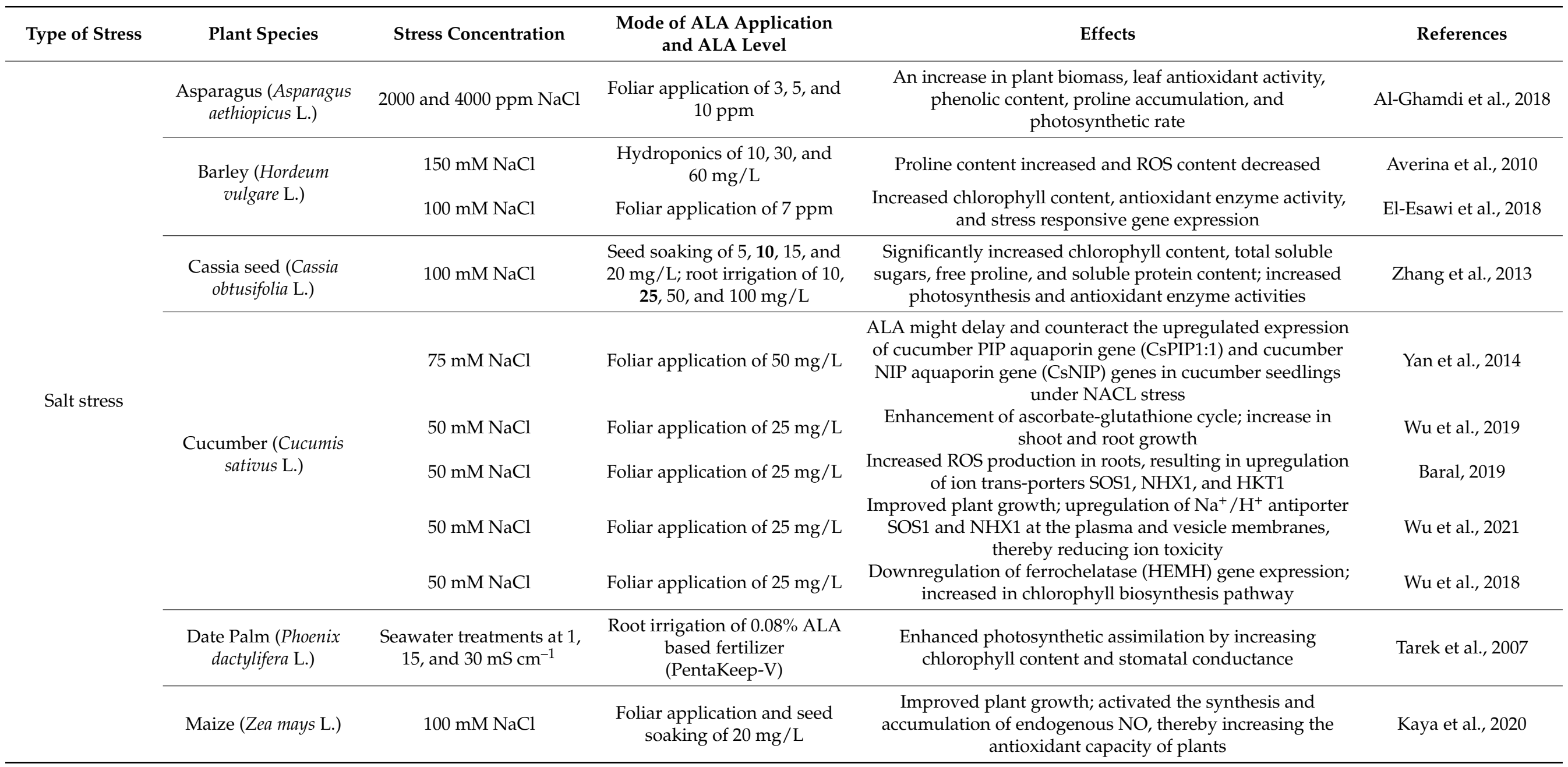


Table 1. Cont.

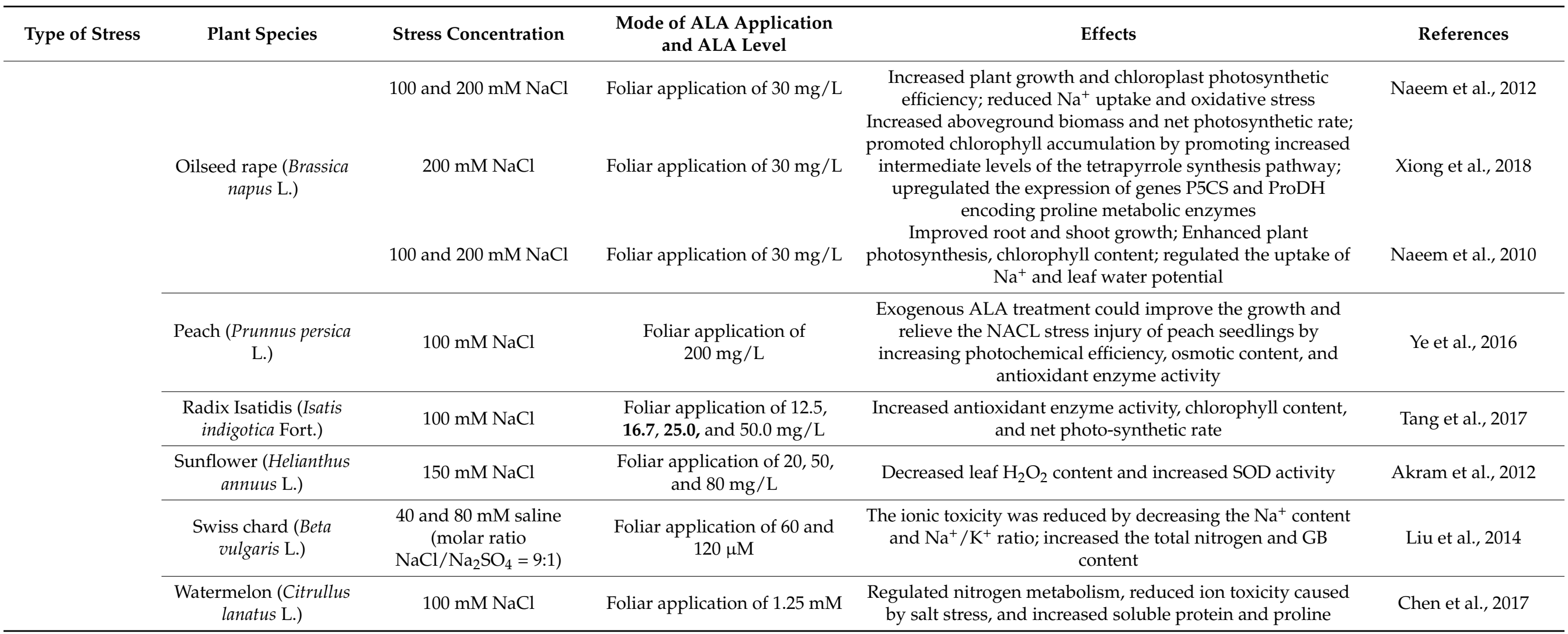


Table 1. Cont.

\begin{tabular}{|c|c|c|c|c|c|}
\hline Type of Stress & Plant Species & $\begin{array}{c}\text { Stress } \\
\text { Concentration }\end{array}$ & $\begin{array}{l}\text { Mode of ALA Application and } \\
\text { ALA Level }\end{array}$ & Effects & References \\
\hline \multirow{9}{*}{$\begin{array}{l}\text { Extreme } \\
\text { Temperature }\end{array}$} & \multirow{3}{*}{$\begin{array}{l}\text { Cucumber (Cucumis } \\
\text { sativus L.) }\end{array}$} & $\begin{array}{l}42 / 38{ }^{\circ} \mathrm{C} \\
\text { (day/night) }\end{array}$ & Foliar application of $3 \mu \mathrm{M}$ & $\begin{array}{c}\text { Reduced ROS content and growth inhibition under heat stress; } \\
\text { enhanced antioxidant enzyme (SOD, CAT, and GPX) activity and } \\
\text { proline content }\end{array}$ & Zhang et al., 2012 \\
\hline & & $\begin{array}{l}12^{\circ} \mathrm{C} / 8^{\circ} \mathrm{C} \\
\text { (day/night) }\end{array}$ & $\begin{array}{l}\text { Foliar application of } 15,30 \text {, and } \\
\qquad 45 \mathrm{mg} / \mathrm{L} \text { ALA }\end{array}$ & $\begin{array}{l}\text { Nutrient contents ( } \mathrm{N}, \mathrm{P}, \mathrm{K}, \mathrm{Mg}, \mathrm{Ca}, \mathrm{Cu}, \mathrm{Fe}, \mathrm{Mn} \text {, and } \mathrm{Zn} \text { ) and } \\
\text { endogenous hormones (JA, IAA, BR, IPA, and } \mathrm{ZR} \text { ) were enhanced } \\
\text { in roots and leaves; Increased chlorophyll content, photosynthetic } \\
\text { capacity, and antioxidant enzymes (SOD, POD, CAT, APX, and } \\
\text { GR); reduced growth inhibition of seedlings by cold stress }\end{array}$ & Anwar et al., 2018 \\
\hline & & $\begin{array}{l}16{ }^{\circ} \mathrm{C} / 8^{\circ} \mathrm{C} \\
\text { (day/night) }\end{array}$ & $\begin{array}{l}\text { Add to the culture substrate of } 10, \\
\text { 20, or } 30 \mathrm{mg} \text { ALA } \cdot \mathrm{kg}^{-1}(\mathrm{ALA} \\
\text { were mixed with a constant } \\
\text { weight of substrate }(\mathrm{kg}))\end{array}$ & $\begin{array}{l}\text { Significantly reduced plant growth inhibition; increased } \\
\text { chlorophyll content, antioxidant enzymes (SOD, CAT, and POD) } \\
\text { activity; reduced accumulation of ROS and malondialdehyde in } \\
\text { roots and leaves }\end{array}$ & Anwar et al., 2020 \\
\hline & \multirow{3}{*}{$\begin{array}{l}\text { Drooping wild } \\
\text { ryegrass (Elymus } \\
\text { nutans Griseb.) }\end{array}$} & $5^{\circ} \mathrm{C}$ & $\begin{array}{l}\text { Seed soaking of } 0.1,0.5,1,5,10 \\
\text { and } 25 \mathrm{mg} / \mathrm{L}\end{array}$ & $\begin{array}{l}\text { Significantly increased seed respiration rate and ATP synthesis and } \\
\text { protected germinating seeds from cold stress; increased GSH, AsA, } \\
\text { total glutathione, and total ascorbate concentrations, as well as }\end{array}$ & Fu et al., 2014 \\
\hline & & $5^{\circ} \mathrm{C}$ & $\begin{array}{l}\text { Foliar application of } 0.5,1,5,10 \\
\text { and } 26 \mathrm{mg} / \mathrm{L}\end{array}$ & $\begin{array}{l}\text { NO might be a downstream signal that mediates ALA-induced } \\
\text { cold tolerance, thereby enhancing antioxidant defense }\end{array}$ & Fu et al., 2015 \\
\hline & & $5^{\circ} \mathrm{C}$ & $\begin{array}{l}\text { Root soaking of } 0.5,1,5,10 \text {, and } \\
\qquad 26 \mathrm{mg} / \mathrm{L}\end{array}$ & $\begin{array}{l}\text { NO might act as a downstream signal to mediate ALA-induced } \\
\text { cold resistance by activating antioxidant defense and PM } \\
\mathrm{H}^{+} \text {-ATPase and maintaining } \mathrm{Na}^{+} \text {and } \mathrm{K}^{+} \text {homeostasis }\end{array}$ & Fu et al., 2016 \\
\hline & Maize (Zea mays L.) & $\begin{array}{l}14^{\circ} \mathrm{C} / 5^{\circ} \mathrm{C} \\
\text { (day/night) }\end{array}$ & Foliar application of $0.15 \mathrm{mM}$ & $\begin{array}{l}\text { Increased proline accumulation, antioxidant enzymes (SOD and } \\
\text { CAT) and RuBP carboxylase activity; prevented reductions in } \\
\text { maize crop yield due to low-temperature stress }\end{array}$ & Wang et al., 2018 \\
\hline & \multirow{2}{*}{$\begin{array}{l}\text { Red pepper (Capsicum } \\
\text { annuum cv. Sena) }\end{array}$} & $4^{\circ} \mathrm{C}$ & $\begin{array}{l}\text { Seed soaking of } 1,10, \mathbf{2 5}, \mathbf{5 0} \text {, and } \\
\qquad 100 \mathrm{ppm}\end{array}$ & $\begin{array}{l}\text { Resulted in higher germination and seedling emergence } \\
\text { percentages, as well as faster germination and seedling emergence }\end{array}$ & Korkmaz et al., 2009 \\
\hline & & $3^{\circ} \mathrm{C}$ & $\begin{array}{l}\text { Seed soaking, foliar spray and } \\
\text { soil drench of } 1,10, \mathbf{2 5}, \mathbf{5 0} \text {, and } \\
\qquad 100 \mathrm{ppm}\end{array}$ & $\begin{array}{l}\text { Improved plant quality, chlorophyll content, sucrose, and proline } \\
\text { content; enhanced SOD activity }\end{array}$ & Korkmaz et al., 2010 \\
\hline
\end{tabular}


Table 1. Cont.

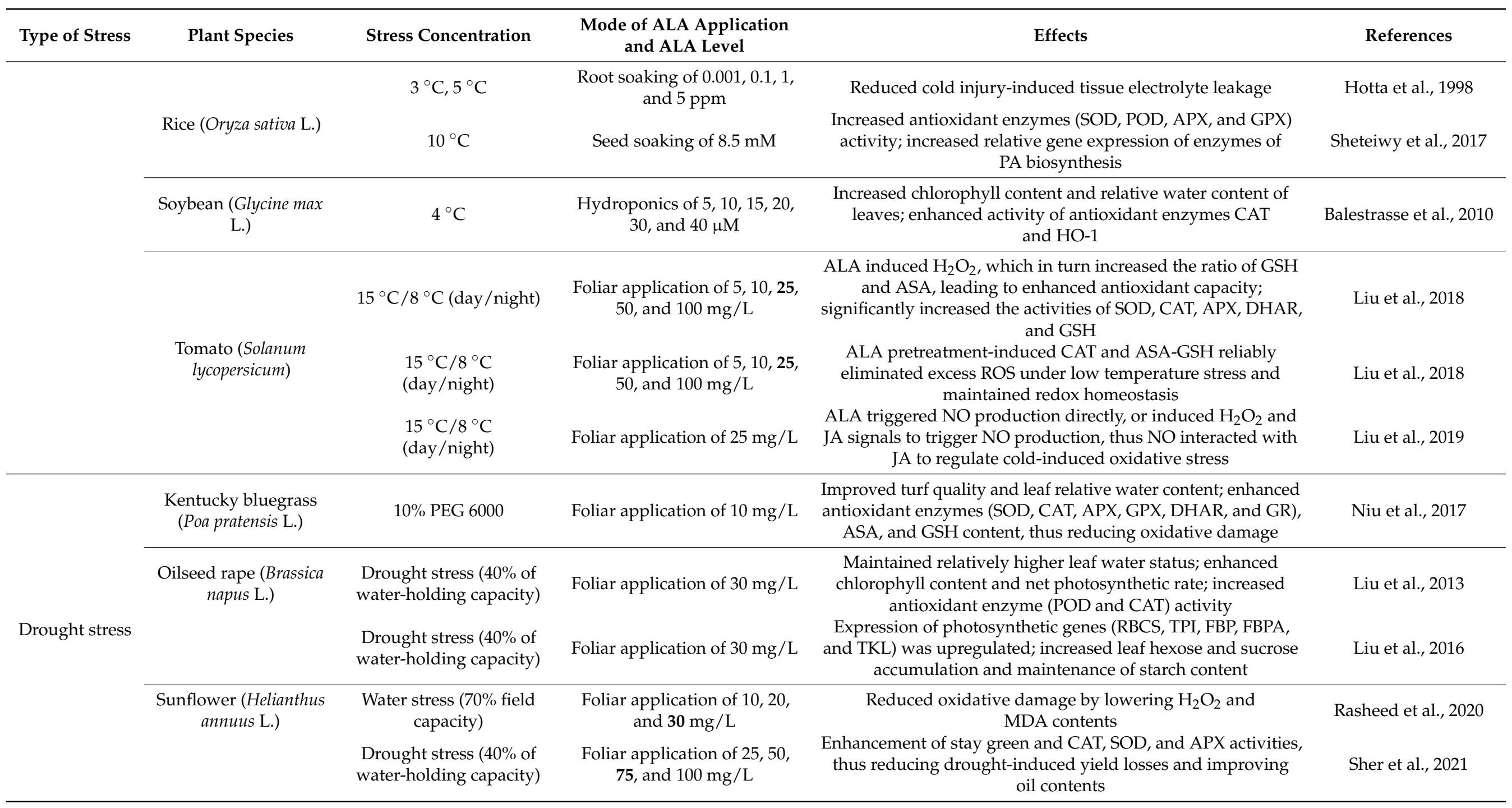


Table 1. Cont.

\begin{tabular}{|c|c|c|c|c|c|}
\hline Type of Stress & Plant Species & Stress Concentration & $\begin{array}{l}\text { Mode of ALA Application } \\
\text { and ALA Level }\end{array}$ & Effects & References \\
\hline & $\begin{array}{l}\text { Wheat (Triticum } \\
\text { aestivum L.) }\end{array}$ & $\begin{array}{l}\text { Irrigation interval of } 7,14, \\
\text { and } 21 \text { days }\end{array}$ & $\begin{array}{l}\text { Foliar application of } 25,50 \\
\text { and } \mathbf{1 0 0} \mathrm{ppm}\end{array}$ & Increased grain yield & Al-Thabet et al., 2006 \\
\hline & & $\begin{array}{l}\text { Water deficit ( } 60 \% \text { and } \\
80 \% \text { of field capacity) }\end{array}$ & $\begin{array}{l}\text { Foliar application of 50, 100, } \\
\text { and } 150 \mathrm{mg} / \mathrm{L}\end{array}$ & $\begin{array}{l}\text { Improved leaf fluorescence ( } \mathrm{qN}, \mathrm{NPQ} \text {, and } \mathrm{Fv} / \mathrm{Fm}) \text {, shoot and } \\
\text { root } \mathrm{K}^{+} \text {, root } \mathrm{Ca}^{2+} \text {, proline, and } \mathrm{GB} \text { accumulation }\end{array}$ & Akram et al., 2018 \\
\hline & & $\begin{array}{l}\text { Water stress ( } 30 \% \\
\text { maximum water capacity) }\end{array}$ & Foliar application of $30 \mathrm{mg} / \mathrm{L}$ & $\begin{array}{c}\text { Increased plant growth, photosynthesis, and chlorophyll } \\
\text { content; reduced the degree of damage to cell membranes } \\
\text { during early nutritional development }\end{array}$ & Ostrowska et al., 2019 \\
\hline \multirow{3}{*}{ UV-B stress } & $\begin{array}{l}\text { lettuce (Lactuca sativa } \\
\text { L.) }\end{array}$ & $3.3 \mathrm{~W} \mathrm{~m}^{-2} \mathrm{UV}-\mathrm{B}$ & $\begin{array}{l}\text { Foliar application of } 10 \text { and } \\
\qquad 25 \mathrm{ppm}\end{array}$ & $\begin{array}{l}\text { ALA treatment resulted in a substantial increase in } \\
\text { phenylalanine ammonia lyase (PAL) and } \gamma \text {-tocopherol } \\
\text { methyltransferase ( } \gamma \text {-TMT) gene expression, antioxidant } \\
\text { enzyme activity, and chlorophyll a and b concentrations. }\end{array}$ & Aksakal et al., 2017 \\
\hline & \multirow[t]{2}{*}{$\begin{array}{l}\text { Pigeon pea (Cajanus } \\
\text { cajan L.) }\end{array}$} & $\begin{array}{l}\text { enhanced UV-B } \\
\left(2.2 \mathrm{~kJ} \mathrm{~m}^{-2} \mathrm{~d}^{-1}\right)\end{array}$ & $\begin{array}{l}\text { Seed soaking of } 25 \text { and } \\
\qquad 100 \mu \mathrm{M}\end{array}$ & \multirow{2}{*}{$\begin{array}{l}\text { Reduced germination time and increased germination index; } \\
\text { upregulated photosynthesis, antioxidant enzymes (CAT, SOD, } \\
\text { and POD), total phenolic content, and total flavonoid content } \\
\text { to balance ROS and reduce UV-B damage to plant productivity } \\
\text { Increased plant growth and growth regulating parameters; } \\
\text { increased enzyme activity and non-enzymatic antioxidant } \\
\text { content in the plant defense system and reduced oxidative } \\
\text { stress in seedlings }\end{array}$} & Gupta et al., 2021 \\
\hline & & $\begin{array}{l}\text { enhanced UV-B } \\
\left(2.2 \mathrm{~kJ} \mathrm{~m}^{-2} \mathrm{~d}^{-1}\right)\end{array}$ & $\begin{array}{l}\text { Seed soaking of } 25 \text { and } \\
\qquad 100 \mu \mathrm{M}\end{array}$ & & Gupta et al., 2021 \\
\hline
\end{tabular}




\subsection{ALA Priming Alleviates Salt Stress}

Salt stress is one of the most deleterious environmental factors that hamper agricultural productivity worldwide by stimulating osmotic stress, ionic toxicity, nutritional disorders, and oxidative stress simultaneously [24,25]. Salt stress results in an imbalance in intracellular ionic homeostasis, triggering the increase in $\mathrm{Na}^{+}$concentration and the decrease in $\mathrm{K}^{+}$concentration in plant tissues [26]. Priming with ALA increases the transcripts and protein accumulations of SOS1 $\left(\mathrm{Na}^{+} / \mathrm{H}^{+}\right.$antiporter) and $\mathrm{HA} 3$ (proton pump) on the plasma membrane (PM) as well as NHX1 $\left(\mathrm{Na}^{+} / \mathrm{H}^{+}\right.$antiporter) and VHA-A (proton pump) on the vesicle membrane compared with the unprimed cucumber (Cucumis sativus) in response to salt stress. The ion transporter proteins SOS1 and NHX1, with the energy provided by proton pump HA3 and VAH-A, help cucumber excrete $\mathrm{Na}^{+}$from the cytoplasm or transfer it to the vesicles, resulting in a high-low-high osmotic potential in the vesicle-protoplastexosome, and thus alleviating ion toxicity induced by salt stress. Pretreatment with ALA upregulates the expression of high-affinity $\mathrm{K}^{+}$transporter protein 1 (HKT1) that regulates $\mathrm{Na}^{+} / \mathrm{K}^{+}$homeostasis in cucumber cells and maintains normal metabolic activities in cells under salt stress conditions $[27,28]$. Proline accumulates in response to salinity and is a common compatible osmolyte in higher plants. Exogenous application of ALA upregulates delta-1-pyrroline-5-carboxylate synthase (P5CS) that controls the rate-limiting step of glutamate-derived proline biosynthesis in Oilseed rape (Brassica napus) and enhances tolerance to salt stress [26,29]. In addition, priming with ALA relieves cell oxidation stress caused by salt stress by improving the activity of antioxidant enzymes, including superoxide dismutase (SOD), catalase (CAT), and peroxidase (POD), and promoting the activity of enzymes involved in the ascorbate-glutathione cycle (AsA-GSH), including ascorbic acid oxidase (AAO), ascorbate peroxidase (APX), glutathione reductase (GR), dehydroascorbic acid reductase (DHAR), and monodehydroascorbic acid reductase (MDHAR) [30-33].

In addition to coping with osmotic stress and oxidative stress caused by salt stress, priming with ALA improves plant salt tolerance by increasing photosynthetic assimilation and promoting nitrogen metabolism. Cassia seed (Cassia obtusifolia), peach (Prunnus persica), and oilseed rape treated with ALA showed an increase in the net photosynthetic rate (Pn) and transpiration rate (Tr), as well as the photochemical efficiency of photosystem II (Fv/Fm) and the non-photochemical quenching (NPQ) during salt stress [29,31,34]. Application of ALA on the leaves leads to swollen chloroplasts and dilation of thylakoid membrane under salt stress conditions, thereby modifying photosynthetic sites and increasing photosynthetic efficiency [35]. Pretreatment with ALA decreases the expression of ferrochelatase, catalyzing the insertion of $\mathrm{Fe}^{2+}$ into protoporphyrin, in Oilseed rape in response to salt stress, thereby inhibiting heme synthesis and increasing chlorophyll synthesis [36]. Additionally, ALA treatment significantly increases the activities of nitrate reductase (NR), glutamine synthetase (GS), glutamate synthase (GOGAT), and glutamate dehydrogenase (GDH) and decreases the activity of nitrite reductase (NiR) in watermelon (Citrullus lanatus). This indicates that ALA regulates nitrogen metabolism to alleviate the cellular toxicity caused by the massive accumulation of nitrate and ammonium salts due to salt stress [37].

The induction of salt tolerance in plants by ALA may be achieved through nitric oxide (NO). ALA treatment increased NO and NOS activity in leaves, suggesting that ALA triggers NO synthesis by activating NOS, and thus improves salt tolerance in maize (Zea mays) [38]. In supporting this hypothesis, ALA-induced salt tolerance is completely abolished by treatment with a scavenger of NO, 2-4-carboxyphenyl-4,4,5,5-tetramethylimidazoline-1oxyl-3-oxide (cPTIO), a stable free radical compound that reacts with $\mathrm{NO}$ to form an imino nitroxide free radical. 


\subsection{ALA Priming Increases Plant Tolerance to Extreme Temperature}

The rate of plant growth and development depends on the temperature surrounding the plant. Considering that plants are sessile, their survival depends on the efficient activation of resistance responses to thermal stress. No organism can withstand the full range of biosphere temperatures, and each species has a specific temperature range represented by minimum, maximum, and optimum temperatures. Extreme temperature events are expected to become more intense and frequent and last longer than those observed in recent years [39]. Extreme temperature adversely affects almost all aspects of plant growth, development, reproduction, and yield [40]. Warm temperatures cause growth restriction, increase the transpiration rate, and damage photosynthetic organs in plants [41], while extreme low temperatures lead to membrane damage, inhibition of photosynthetic properties, and oxidative stress [42]. ALA-pretreated cucumber leaves had higher antioxidant enzyme activity, higher levels of proline and soluble sugar content, and weaker growth inhibition under high-temperature stress conditions [43]. Priming with ALA increases germination and seedling emergence in red pepper (Capsicum annuum) and reduces tissue electrolyte leakage in rice (Oryza sativa) under cold stress [44,45]. Pretreatment with ALA also increases chlorophyll content and photosynthetic capacity of cucumber and enhances ribulose-1,5-bisphosphate (RuBP) carboxylase activity in maize under cold stress conditions [46-48]. Furthermore, ALA treatment also improved the antioxidant capacity of plants in response to cold stress by increasing the activities of SOD, APX, GR, CAT, and heme oxygenase-1 (HO-1) in red pepper, drooping wild ryegrass (Elymus nutans), and soybean plants (Glycine max) [49-51]. Interestingly, ALA priming upregulates the expression levels of respiratory burst oxidase homologue1 (RBOH1) in tomato (Solanum lycopersicum) and leads to the production of $\mathrm{H}_{2} \mathrm{O}_{2}$, which serves as a signaling molecule to activate defense against cold stress [52].

In addition, studies in drooping wild ryegrass and tomato suggest that ALA may directly trigger $\mathrm{NO}$ production or indirectly promote $\mathrm{NO}$ production by inducing jasmonic acid (JA) and $\mathrm{H}_{2} \mathrm{O}_{2}[53,54]$. $\mathrm{NO}$ activates antioxidant enzyme activity and $\mathrm{PM} \mathrm{H}^{+}$-ATPase and maintains $\mathrm{Na}^{+} / \mathrm{K}^{+}$homeostasis, thereby reducing cold stress-induced injury [55]. Moreover, priming with ALA induces the expressions of genes involved in the biosynthesis of PA in rice [7], which enhances tolerance to cold stress [56]. Besides, studies in cucumber have shown that ALA priming increases tolerance to cold stress by regulating the biosynthesis of classic phytohormones such as JA, indole-3-acetic acid (IAA), brassinosteroid (BR), cytokinins (CKs), gibberellin (GA4), and abscisic acid (ABA) during cold stress [47]. In the future, further studies are needed to investigate how ALA regulates phytohormone synthesis under cold stress conditions and whether it regulates key components of the phytohormone signaling pathway so as to further reveal the molecular mechanisms by which ALA enhances low-temperature tolerance in plants.

\subsection{ALA Priming Mitigates Drought-Induced Damage}

Under natural and agricultural conditions, plants are subject to various environmental stresses during growth and development. Among them, drought is one of the most severe environmental stresses, which occurs as a result of temperature dynamics, light intensity, and low rainfall and affects plant biomass production, quality, and energy. Drought stress limits photosynthesis in plants by causing stomatal closure and reduced water content, as well as leading to excessive production of reactive oxygen species, which can inhibit plant growth [57]. ALA pretreatment can maintain moisture in the seedlings of oilseed rape and Kentucky bluegrass (Poa pratensis), thus enhancing leaf relative water content (RWC) $[58,59]$. It can also increase the contents of proline and foliar $\mathrm{N}$ in wheat (Triticum aestivum), as well as $\mathrm{Ca}^{2+}$ in the roots under drought conditions [60-62]. In addition, in studies with Kentucky bluegrass and sunflower (Helianthus annuus), priming with ALA increases the activities of antioxidant enzymes such as catalase (CAT), superoxide dismutase (SOD), ascorbate peroxidase (APX), and glutathione reductase (GR), which reduce the production of ROS, including $\mathrm{H}_{2} \mathrm{O}_{2}$ content and $\mathrm{O}_{2}{ }^{\bullet-}$ production, thereby 
improving tolerance against drought stress $[58,63]$. Priming with ALA also preserves plant photosynthesis in oilseed rape, wheat, and sunflower by suppressing chlorophyll degradation and increasing photosynthetic rate $(\mathrm{Pn})$ during drought stress $[59,61,64,65]$. Furthermore, pretreatment with ALA induces the expressions of enzymes involved in the Calvin cycle such as triose-3-phosphate isomerase (TPI) and fructose-1,6-bisphosphate aldolase (FBPA) [66]. Interestingly, in addition to enhance the drought resistance of plants, ALA priming also improves waterlogging tolerance in Fig (Ficus carica), with higher levels of antioxidant enzyme activity, photosynthetic efficiency, and root respiration [67].

\subsection{ALA Priming Attenuates UV-B-Induced Damage}

Ultraviolet-B (UV-B) radiation is a component of sunlight that induces several plant photomorphogenic responses, including hypocotyl growth inhibition and cotyledon curling [68]. High-intensity UV-B injures plants by damaging DNA, impaired photosynthesis, and cell death, and triggering the accumulation of ROS [69]. Priming with ALA was reported to significantly reduce plant damage from UV-B radiation by promoting photosynthesis, enhancing antioxidant capacity, and improving nitrogen metabolism. As a key precursor of chlorophyll biosynthesis, ALA alleviated the deficiency of chlorophyll biosynthesis during UV-B stress; ALA pretreatment upregulates the expression of genes involved in chlorophyll biosynthesis such as glutamyl-tRNA reductase (HEMA1), Mgchelatase (CHLH), and protochlorophyllide oxidoreductase (POR) in pigeon pea (Cajanus cajan), thus promoting plant photosynthesis during UV-B stress [8,70]. In addition, ALA priming-increased activities of antioxidant enzymes are essential for lettuce (Lactuca sativa) resistance to UV-B stress [71]. In addition to enzymatic antioxidants, ALA also increases the content of non-enzymatic antioxidants such as flavonoids and phenolics [8]. Under UV-B stress conditions, ALA priming significantly improves the activities of nitrate reductase (NR), nitrite reductase (NiR), glutamine synthetase (GS), and glutamate synthase (GOGAT), and then increases the levels of $\mathrm{NO}_{3}{ }^{-}$and $\mathrm{NO}_{2}{ }^{-}$in the seedlings of pigeon pea [70]. Collectively, ALA priming contributes to UV-B tolerance by regulating photosynthesis, antioxidant, and nitrogen metabolism in plants.

\section{Application of ALA in Agriculture and Medicine}

ALA is a growth regulator that regulates the growth and development of plants at different growth stages. Soaking seeds with ALA reduces the germination time and increases the germination index of pigeon pea, and promotes Arabidopsis thaliana root elongation by regulating auxin transport [8,72]. ALA significantly increased yields through root or foliar fertilization in grapevines (Vitis vinifera) [73]. The shoot application of ALA stimulates the growth of maize seedlings [74]. ALA-based fertilizer can significantly increase the growth of tomato and date palm (Phoenix dactylifera) [75-77]. Rhizospheric application of ALA significantly increases the endogenous ALA content and improves fruit coloration and interior qualities in apple cultivar (Malus domestica) [78].

A dose-effect was observed in the application of ALA in plants, implying that high concentrations of ALA are harmful to plants. For example, low concentrations of ALA (0.5 or $1 \mathrm{mg} / \mathrm{L}$ ) increase the biomass and the content of various bioactive compounds in oilseed rape, whereas high concentrations of ALA ( 5 or $10 \mathrm{mg} / \mathrm{L}$ ) cause oxidative stress, which is detrimental to the growth of oilseed rape [79]. Using this property, ALA is also used as a "photodynamic herbicide" in agriculture [15]. Plants treated with high concentrations of ALA accumulate excess PpIX, which produces ROS in the light, thus causing damage to the plants [80]. Foliar spray of $5 \mathrm{mM}$ ALA resulted in the formation of white necrotic spots on the leaves of rice plants [81]. More interestingly, some herbicides such as diphenyl ether herbicides kill plants by stimulating excessive ALA production, which leads to the accumulation of PpIX in plant cells [82]. As expected, these herbicides are more toxic when used in combination with ALA and enhance weed control [83].

In medicine, ALA is widely used in photodynamic therapy (PDT) [84-86], a treatment for certain cancers and precancerous diseases using photosensitizers and lasers. ALA 
itself is not a photosensitizer, but a precursor substance for the photosensitizer PpIX [87]. When excessive ALA is applied, it is selectively absorbed by proliferating active cells and converted intracellularly into porphyrins such as PpIX. Intracellular PpIX can be activated, leading to ROS generation after exposure to lasers, which is ultimately toxic to tumor cells [88]. Topical ALA-PDT has also been used to treat the tumor or non-tumor dermatoses, which is non-invasive and has better therapeutic effects compared with conventional treatments [89-91].

\section{Conclusions and Future Perspectives}

Dramatic global climate change has triggered high temperatures and droughts in some regions and floods in others, seriously threatening crop growth and food security worldwide. Priming significantly improves plant tolerance to various biotic and abiotic stresses, which provides a strategy for improving crop yield and quality in a non-optimal environment [1]. ALA, as a plant growth regulator and a precursor substance of chlorophyll, plays an important role in inducing defense priming [15,16]. Here, we review the remarkable role of ALA priming in plant tolerance. Priming with ALA can activate $\mathrm{NO}, \mathrm{H}_{2} \mathrm{O}_{2}$, and hormone signals and strengthen photosynthesis, antioxidant capacity, osmoregulation, and nitrogen assimilation, thus helping plants to obtain a stronger ability to cope with abiotic stresses. High concentrations of ALA function as an herbicide because it causes oxidative stress. Curiously, different plant species have different adaptations to high concentrations of ALA, which may be owing to differences in photosynthetic patterns.

Currently, the use of ALA to activate plant resistance is mainly through seed dips, foliar sprays, and soil watering. The use of operable promoters to construct transgenic plants to produce ALA will facilitate the study of the molecular mechanisms by which ALA regulates plant development and increases plant stress tolerance. Regretfully, most of the current studies on ALA priming have focused on the measurement of physiological parameters; we still know very little about its molecular or biochemical mechanisms. One of the reasons may be that we do not yet dissect the signaling pathways of ALA. For example, is there an ALA receptor? and what are the key components of the ALA signaling pathway? We could address these issues in two ways. (i) Identification of the key components of ALA signaling by screening for mutants with an altered response to ALA through a forward genetic approach. (ii) Identification of ALA-binding proteins (ABP) through biochemical pathways, and then investigation of their functions through a reverse genetic strategy using genome editing techniques. The availability of these genetic materials will help to reveal the physiological functions of ALA and the molecular basis of ALA priming-enhanced plant resistance against numerous environmental stresses.

Author Contributions: Conceptualization, Z.L.; writing-original draft preparation, S.T.; writingreview and editing, Z.L.; visualization, J.C.; supervision, Z.L. and X.X.; project administration, Z.L.; funding acquisition, Z.L. All authors have read and agreed to the published version of the manuscript.

Funding: This work was funded by grants from the National Natural Science Foundation of China (32170345, 31970196, and 32011540381 to Z.L.), and the startup funding for plant aging research from Beijing Forestry University (BJFU2021YJRC00600K).

Institutional Review Board Statement: Not applicable.

Informed Consent Statement: Not applicable.

Data Availability Statement: Not applicable.

Acknowledgments: We sincerely apologize to those authors whose work is not included in this review because of space limitations.

Conflicts of Interest: The authors declare no conflict of interest. 


\section{References}

1. Martinez-Medina, A.; Flors, V.; Heil, M.; Mauch-Mani, B.; Pieterse, C.M.J.; Pozo, M.J.; Ton, J.; van Dam, N.M.; Conrath, U. Recognizing Plant Defense Priming. Trends Plant Sci. 2016, 21, 818-822. [CrossRef] [PubMed]

2. Mauch-Mani, B.; Baccelli, I.; Luna, E.; Flors, V. Defense Priming: An Adaptive Part of Induced Resistance. Annu. Rev. Plant Biol. 2017, 68, 485-512. [CrossRef] [PubMed]

3. Díaz-Valle, A.; López-Calleja, A.C.; Alvarez-Venegas, R. Enhancement of Pathogen Resistance in Common Bean Plants by Inoculation With Rhizobium etli. Front. Plant Sci. 2019, 10, 1317. [CrossRef]

4. $\quad$ Kim, J.I.; Baek, D.; Park, H.C.; Chun, H.J.; Oh, D.H.; Lee, M.K.; Cha, J.Y.; Kim, W.Y.; Kim, M.C.; Chung, W.S.; et al. Overexpression of Arabidopsis YUCCA6 in potato results in high-auxin developmental phenotypes and enhanced resistance to water deficit. Mol. Plant 2013, 6, 337-349. [CrossRef] [PubMed]

5. Singh, P.; Yekondi, S.; Chen, P.-W.; Tsai, C.-H.; Yu, C.-W.; Wu, K.; Zimmerli, L. Environmental History Modulates Arabidopsis Pattern-Triggered Immunity in a HISTONE ACETYLTRANSFERASE1-Dependent Manner. Plant Cell 2014, 26, $2676-2688$. [CrossRef]

6. Savvides, A.; Ali, S.; Tester, M.; Fotopoulos, V. Chemical Priming of Plants Against Multiple Abiotic Stresses: Mission Possible? Trends Plant Sci. 2016, 21, 329-340. [CrossRef]

7. Mohamed, S.; Hangqi, S.; Jungui, X.; Yajing, G.; Wenjian, S.; Jin, H. Seed polyamines metabolism induced by seed priming with spermidine and 5-aminolevulinic acid for chilling tolerance improvement in rice (Oryza sativa L.) seedlings. Environ. Exp. Bot. 2017, 137, 58-72.

8. Gupta, D.; Prasad, S.M. Priming with 5-aminolevulinic acid (ALA) attenuates UV-B induced damaging effects in two varieties of Cajanus cajan L. seedlings by regulating photosynthetic and antioxidant systems. S. Afr. J. Bot. 2021, 138, 129-140. [CrossRef]

9. Conrath, U.; Beckers, G.J.M.; Langenbach, C.J.G.; Jaskiewicz, M.R. Priming for Enhanced Defense. Annu. Rev. Phytopathol. 2015, 53, 97-119. [CrossRef]

10. Tanou, G.; Filippou, P.; Belghazi, M.; Job, D.; Diamantidis, G.; Fotopoulos, V.; Molassiotis, A. Oxidative and nitrosative-based signaling and associated post-translational modifications orchestrate the acclimation of citrus plants to salinity stress. Plant $J$. 2012, 72, 585-599. [CrossRef]

11. Li, M.; Yu, G.; Ma, J.; Liu, P. Interactions of importers in long-distance transmission of wound-induced jasmonate. Plant Signal. Behav. 2021, 16, 1886490. [CrossRef] [PubMed]

12. Lee, H.-R.; Lee, S.; Park, S.; van Kleeff, P.J.M.; Schuurink, R.C.; Ryu, C.-M. Transient Expression of Whitefly Effectors in Nicotiana benthamiana Leaves Activates Systemic Immunity Against the Leaf Pathogen Pseudomonas syringae and Soil-Borne Pathogen Ralstonia solanacearum. Front. Ecol. Evol. 2018, 6, 90. [CrossRef]

13. Ramírez-Carrasco, G.; Martínez-Aguilar, K.; Alvarez-Venegas, R. Transgenerational Defense Priming for Crop Protection against Plant Pathogens: A Hypothesis. Front. Plant Sci. 2017, 8, 696. [CrossRef] [PubMed]

14. Antoniou, C.; Savvides, A.; Christou, A.; Fotopoulos, V. Unravelling chemical priming machinery in plants: The role of reactive oxygen-nitrogen-sulfur species in abiotic stress tolerance enhancement. Curr. Opin. Plant Biol. 2016, 33, 101-107. [CrossRef]

15. Sasaki, K.; Watanabe, M.; Tanaka, T.; Tanaka, T. Biosynthesis, biotechnological production and applications of 5-aminolevulinic acid. Appl. Microbiol. Biotechnol. 2002, 58, 23-29. [CrossRef]

16. Agrawal, S.; Karcher, D.; Ruf, S.; Bock, R. The Functions of Chloroplast Glutamyl-tRNA in Translation and Tetrapyrrole Biosynthesis1 [OPEN]. Plant Physiol. 2020, 183, 263-276. [CrossRef]

17. Iida, K.; Kajiwara, M. Carbon Source Dependence of the Ratio of $\delta$-Aminolevulinic Acid Biosynthesis via the C5 and Shemin Pathways in Euglena Gracilis (Euglenophyceae)1. J. Phycol. 2008, 44, 292-298. [CrossRef]

18. Wu, Y.; Liao, W.; Dawuda, M.M.; Hu, L.; Yu, J. 5-Aminolevulinic acid (ALA) biosynthetic and metabolic pathways and its role in higher plants: A review. Plant Growth Regul. 2019, 87, 357-374. [CrossRef]

19. Senge, M.O.; Ryan, A.A.; Letchford, K.A.; MacGowan, S.A.; Mielke, T. Chlorophylls, Symmetry, Chirality, and Photosynthesis. Symmetry 2014, 6, 781-843. [CrossRef]

20. Kang, Z.; Zhang, J.; Zhou, J.; Qi, Q.; Du, G.; Chen, J. Recent advances in microbial production of $\delta$-aminolevulinic acid and vitamin B12. Biotechnol. Adv. 2012, 30, 1533-1542. [CrossRef]

21. Yang, P.; Liu, W.; Cheng, X.; Wang, J.; Wang, Q.; Qi, Q.; Liu, S.-J. A New Strategy for Production of 5-Aminolevulinic Acid in Recombinant Corynebacterium glutamicum with High Yield. Appl. Environ. Microbiol. 2016, 82, 2709-2717. [CrossRef]

22. Noh, M.H.; Lim, H.G.; Park, S.; Seo, S.W.; Jung, G.Y. Precise flux redistribution to glyoxylate cycle for 5-aminolevulinic acid production in Escherichia coli. Metab. Eng. 2017, 43, 1-8. [CrossRef] [PubMed]

23. Chen, B.; Li, J.; Feng, Y.; Le, K.; Zai, Y.; Tang, X.; Sun, Y.; Zeng, X.; Lin, L. Green and mild production of 5-aminolevulinic acid from algal biomass. Korean J. Chem. Eng. 2021, 38, 899-905. [CrossRef]

24. Mohsin, T.; Adnan Noor, S. An insight into salt stress tolerance mechanisms of Chenopodium album. Environ. Sci. Pollut. Res. 2017, 24, 16531-16535.

25. Zhao, S.; Zhang, Q.; Liu, M.; Zhou, H.; Ma, C.; Wang, P. Regulation of Plant Responses to Salt Stress. Int. J. Mol. Sci. 2021, 22, 4609. [CrossRef] [PubMed]

26. Liyun, L.; Nguyen Tran, N.; Akihiro, U.; Hirofumi, S. Effects of 5-aminolevulinic acid on Swiss chard (Beta vulgaris L. subsp. cicla) seedling growth under saline conditions. Plant Growth Regul. 2014, 74, 219-228.

27. Anirban, B. Strawberries under salt stress: ALA and ROS to the rescue. Physiol. Plant. 2019, 167, 2-4. 
28. Yue, W.; Na, L.; Linli, H.; Weibiao, L.; Zhongqi, T.; Xuemei, X.; Jian, L.; Jianming, X.; Alejandro, C.-U.; Jihua, Y. 5-Aminolevulinic Acid Improves Morphogenesis and $\mathrm{Na}^{+}$Subcellular Distribution in the Apical Cells of Cucumis sativus L. under Salinity Stress. Front. Plant Sci. 2021, 12, 404.

29. Jun-Lan, X.; Hang-Chao, W.; Xiao-Yu, T.; Chun-Lei, Z.; Muhammad Shahbaz, N. 5-aminolevulinic acid improves salt tolerance mediated by regulation of tetrapyrrole and proline metabolism in Brassica napus L. seedlings under NaCl stress. Plant Physiol. Biochem. 2018, 124, 88-99.

30. Nudrat Aisha, A.; Muhammad, A.; Al-Qurainy, F. Aminolevulinic acid-induced changes in some key physiological attributes and activities of antioxidant enzymes in sunflower (Helianthus annuus L.) plants under saline regimes. Sci. Hortic-Amst. 2012, 142, 143-148.

31. Jia, Y.; Qiang, C.; Ting, T.; Gui, W.; Feng, X. Promotive effects of 5-Aminolevulinic acid on growth, photosynthetic gas exchange, chlorophyll, and antioxidative enzymes under salinity stress in Prunnus persica (L.) Batseh Seedling. Emir. J. Food Agric. 2016, 786-795. [CrossRef]

32. Mohamed, E.-E.; Ibrahim, A.; Abdulaziz, A.; Hayssam, A.; Aisha, A.; Jacques, W.; Margaret, A. Genetic Variation and Alleviation of Salinity Stress in Barley (Hordeum vulgare L.). Molecules 2018, 23, 2488.

33. Yue, W.; Linli, H.; Weibiao, L.; Mohammed Mujitaba, D.; Jian, L.; Jianming, X.; Zhi, F.; Alejandro, C.-U.; Jihua, Y. Foliar application of 5-aminolevulinic acid (ALA) alleviates $\mathrm{NaCl}$ stress in cucumber (Cucumis sativus L.) seedlings through the enhancement of ascorbate-glutathione cycle. Sci. Hortic-Amst. 2019, 257, 108761.

34. Chun-Ping, Z.; Yi-Cun, L.; Feng-Gang, Y.; Shi-Jun, H.; Hai-Ying, L.; Ping, H. Role of 5-aminolevulinic acid in the salinity stress response of the seeds and seedlings of the medicinal plant Cassia obtusifolia L. Bot. Stud. 2013, 54, 1-13.

35. Muhammad, S.N.; Hasitha, W.; Hongbo, L.; Dan, L.; Rashid, A.; Ejaz Ahmad, W.; Ling, X.; Weijun, Z. 5-Aminolevulinic acid alleviates the salinity-induced changes in Brassica napus as revealed by the ultrastructural study of chloroplast. Plant Physiol. Biochem. 2012, 57, 84-92.

36. Yue, W.; Xin, J.; Weibiao, L.; Linli, H.; Mohammed, M.D.; Xingjie, Z.; Zhongqi, T.; Tingyu, G.; Jihua, Y. 5-Aminolevulinic Acid (ALA) Alleviated Salinity Stress in Cucumber Seedlings by Enhancing Chlorophyll Synthesis Pathway. Front. Plant Sci. 2018, 9, 635.

37. Chen, G.; Fan, P.S.; Feng, W.M.; Guan, A.Q.; Lu, Y.Y.; Wan, Y.L. Effects of 5-aminolevulinic acid on nitrogen metabolism and ion distribution of watermelon seedlings under salt stress. Russ. J. Plant Physiol. 2017, 64, 116-123. [CrossRef]

38. Cengiz, K.; Muhammad, A. Nitric Oxide is Required for Aminolevulinic Acid-Induced Salt Tolerance by Lowering Oxidative Stress in Maize (Zea mays). J. Plant Growth Regul. 2020, 40, 617-627.

39. Hatfield, J.L.; Prueger, J.H. Temperature extremes: Effect on plant growth and development. Weather Clim. Extrem. 2015, 10, 4-10. [CrossRef]

40. Liu, Q.; Yan, S.; Yang, T.; Zhang, S.; Chen, Y.-Q.; Liu, B. Small RNAs in regulating temperature stress response in plants. J. Integr. Plant Biol. 2017, 59, 774-791. [CrossRef]

41. Fahad, S.; Bajwa, A.A.; Nazir, U.; Anjum, S.A.; Farooq, A.; Zohaib, A.; Sadia, S.; Nasim, W.; Adkins, S.; Saud, S.; et al. Crop Production under Drought and Heat Stress: Plant Responses and Management Options. Front. Plant Sci. 2017, 8, 1147. [CrossRef]

42. Khan, T.A.; Fariduddin, Q.; Yusuf, M. Low-temperature stress: Is phytohormones application a remedy? Environ. Sci. Pollut. Res. 2017, 24, 21574-21590. [CrossRef] [PubMed]

43. Zhang, J.; Li, D.M.; Gao, Y.; Yu, B.; Xia, C.X.; Bai, J.G. Pretreatment with 5-aminolevulinic acid mitigates heat stress of cucumber leaves. Biol. Plant. 2012, 56, 780-784. [CrossRef]

44. Ahmet, K.; Yakup, K. Promotion by 5-aminolevulenic acid of pepper seed germination and seedling emergence under lowtemperature stress. Sci. Hortic-Amst. 2009, 119, 98-102.

45. Hotta, Y.; Tanaka, T.; Luo, B.; Takeuchi, Y.; Konnai, M. Improvement of Cold Resistance in Rice Seedlings by 5-Aminolevulinic Acid. J. Pestic. Sci. 1998, 23, 29-33. [CrossRef]

46. Wang, Y.; Li, J.; Gu, W.; Zhang, Q.; Tian, L.; Guo, S.; Wei, S. Exogenous application of 5-aminolevulinic acid improves lowtemperature stress tolerance of maize seedlings. Crop Pasture Sci. 2018, 69, 587-593. [CrossRef]

47. Ali, A.; Yan, Y.; Yumei, L.; Yansu, L.; Xianchang, Y. 5-Aminolevulinic Acid Improves Nutrient Uptake and Endogenous Hormone Accumulation, Enhancing Low-Temperature Stress Tolerance in Cucumbers. Int. J. Mol. Sci. 2018, 19, 3379.

48. Ali, A.; Jun, W.; Xianchang, Y.; Chaoxing, H.; Yansu, L. Substrate Application of 5-Aminolevulinic Acid Enhanced Lowtemperature and Weak-light Stress Tolerance in Cucumber (Cucumis sativus L.). Agronomy 2020, 10, 472.

49. Karina, B.B.; María, L.T.; Alcira, B.; Guillermo, O.N. The role of 5-aminolevulinic acid in the response to cold stress in soybean plants. Phytochemistry 2010, 71, 2038-2045.

50. Ahmet, K.; Yakup, K.; Ali Rıza, D. Enhancing chilling stress tolerance of pepper seedlings by exogenous application of 5aminolevulinic acid. Environ. Exp. Bot. 2010, 67, 495-501.

51. Juanjuan, F.; Yongfang, S.; Xitong, C.; Yuefei, X.; Tianming, H. Exogenous 5-aminolevulenic acid promotes seed germination in Elymus nutans against oxidative damage induced by cold stress. PLoS ONE 2014, 9, e107152.

52. Liu, T.; Xu, J.; Zhang, J.; Li, J.; Hu, X. Exogenous 5-aminolevulinic acid pretreatment ameliorates oxidative stress triggered by low-temperature stress of Solanum lycopersicum. Acta Physiol Plant 2018, 40, 210. [CrossRef]

53. Juanjuan, F.; Xitong, C.; Yongfang, S.; Yanjun, M.; Yuefei, X.; Tianming, H. Nitric Oxide Mediates 5-Aminolevulinic Acid-Induced Antioxidant Defense in Leaves of Elymus nutans Griseb. Exposed to Chilling Stress. PLoS ONE 2015, 10, e0130367. 
54. Tao, L.; Jiaojiao, X.; Jianming, L.; Xiaohui, $\mathrm{H}$. $\mathrm{NO}$ is involved in JA- and $\mathrm{H}_{2} \mathrm{O}_{2}$-mediated ALA-induced oxidative stress tolerance at low temperatures in tomato. Environ. Exp. Bot. 2019, 161, 334-343.

55. Fu, J.J.; Chu, X.T.; Sun, Y.F.; Xu, Y.F.; Hu, T.M. Involvement of nitric oxide in 5-aminolevulinic acid-induced antioxidant defense in roots of Elymus nutans exposed to cold stress. Biol. Plant. 2016, 60, 585-594. [CrossRef]

56. Megha, S.; Basu, U.; Kav, N.N.V. Metabolic engineering of cold tolerance in plants. Biocatal. Agric. Biotechnol. 2014, 3, 88-95. [CrossRef]

57. Yuan, S.; Cuiting, W.; Han, Y.H.C.; Honghua, R. Response of Plants to Water Stress: A Meta-Analysis. Front. Plant Sci. 2020, 11, 978.

58. Kuiju, N.; Xiang, M.; Guoling, L.; Huiling, M.; Zhifeng, J.; Wenhui, L.; Qianqian, Y. 5-Aminolevulinic acid modulates antioxidant defense systems and mitigates drought-induced damage in Kentucky bluegrass seedlings. Protoplasma 2017, $254,2083-2094$.

59. Dan, L.; Lingtong, W.; Muhammad Shahbaz, N.; Hongbo, L.; Xiangqin, D.; Ling, X.; Fan, Z.; Weijun, Z. 5-Aminolevulinic acid enhances photosynthetic gas exchange, chlorophyll fluorescence and antioxidant system in oilseed rape under drought stress. Acta Physiol. Plant 2013, 35, 2747-2759.

60. Al-Thabet, S.S. Promotive Effect of 5-amino Levulinic Acid on Growth and Yield of Wheat Grown under Dry Conditions. J. Agron. 2006, 5, 45-49. [CrossRef]

61. Nudrat Aisha, A.; Shamim, K.; Naila, F.; Muhammad, A.; Fahad, A.-Q. 5-Aminolevulinic Acid Induces Regulation in Growth, Yield and Physio-Biochemical Characteristics of Wheat under Water Stress. Sains Malays. 2018, 47, 661-670.

62. Kosar, F.; Akram, N.A.; Ashraf, M. Exogenously-applied 5-aminolevulinic acid modulates some key physiological characteristics and antioxidative defense system in spring wheat (Triticum aestivum L.) seedlings under water stress. S. Afr. J. Bot. 2015, 96, 71-77. [CrossRef]

63. Ahmad, S.; Anum Samreen, T.; Abdul, S.; Ahmad, N.; Abdul, Q.; Shabir, H.; Abdul, M. Foliage application of 5-aminolevulinic acid alleviates drought stress in sunflower (Helianthus annuus L.) through improving stay green and antioxidant enzymes activities. Acta Physiol. Plant 2021, 43, 1-7.

64. Ostrowska, A.; Biesaga-Kościelniak, J.; Grzesiak, M.T.; Hura, T. Physiological responses of spring wheat to 5-aminolevulinic acid under water stress applied at seedling stage. Cereal Res. Commun. 2019, 47, 32-41. [CrossRef]

65. Rizwan, R.; Humaira, Y.; Iqbal, H.; Muhammad, I.; Muhammad Arslan, A.; Abida, P. Exogenously applied 5-aminolevulinic acid modulates growth, secondary metabolism and oxidative defense in sunflower under water deficit stress. Physiol. Mol. Biol. Plants 2020, 26, 489-499.

66. Liu, D.; Hu, L.Y.; Ali, B.; Yang, A.G.; Wan, G.L.; Xu, L.; Zhou, W.J. Influence of 5-aminolevulinic acid on photosynthetically related parameters and gene expression in Brassica napus L. under drought stress. Soil Sci. Plant Nutr. 2016, 62, 254-262. [CrossRef]

67. Yuyan, A.; Lin, Q.; Liangju, W. ALA Pretreatment Improves Waterlogging Tolerance of Fig Plants. PLoS ONE 2016, 11, e0147202.

68. Dotto, M.; Casati, P. Developmental reprogramming by UV-B radiation in plants. Plant Sci. 2017, 264, 96-101. [CrossRef]

69. Shi, C.; Liu, H. How plants protect themselves from ultraviolet-B radiation stress. Plant Physiol. 2021, 187, 1096-1103. [CrossRef]

70. Divya, G.; Sheo Mohan, P. 5-aminolevulinic acid (ALA) regulates photosynthetic performance and nitrogen metabolism status in UV-B challenged Cajanus cajan L. seedlings. J. Plant Biochem. Biot. 2021. [CrossRef]

71. Ozkan, A.; Omer Faruk, A.; Feyza Icoglu, A.; Ferhunde, A. Exogenous 5-aminolevulinic acid alleviates the detrimental effects of UV-B stress on lettuce (Lactuca sativa L) seedlings. Acta Physiol Plant 2017, $39,55$.

72. An, Y.Y.; Cheng, D.X.; Rao, Z.X.; Sun, Y.P.; Tang, Q.; Wang, L.J. 5-Aminolevulinic acid (ALA) promotes primary root elongation through modulation of auxin transport in Arabidopsis. Acta Physiol. Plant 2019, 41, 6. [CrossRef]

73. Watanabe, K.; Nishihara, E.; Watanabe, S.; Tanaka, T.; Takahashi, K.; Takeuchi, Y. Enhancement of growth and fruit maturity in 2-year-old grapevines cv. Delaware by 5-aminolevulinic acid. Plant Growth Regul. 2006, 49, 35-42. [CrossRef]

74. Yonezawa, T.; Sunohara, Y.; Matsumoto, H. Involvement of heme synthesis in the growth stimulation of maize seedlings by 5-aminolevulinic acid. Weed Biol. Manag. 2015, 15, 53-60. [CrossRef]

75. Tarek, Y.; Mohamed, A.A. Mechanisms of Enhancing Photosynthetic Gas Exchange in Date Palm Seedlings (Phoenix dactylifera L.) under Salinity Stress by a 5-Aminolevulinic Acid-based Fertilizer. J. Plant Growth Regul. 2007, 27, 1-9.

76. Mohamed, A.A. Promotive effects of a 5-aminolevulinic acid-based fertilizer on growth of tissue culture-derived date palm plants (Phoenix dactylifera L.) during acclimatization. Sci. Hortic-Amst. 2008, 118, 48-52.

77. Mahmoud, A.; Ali, A. Influence of Pentakeep-V on the nutrient interaction and availability for tomato production. Emir. J. Food Agric. 2010, 22, 174-188.

78. Zheng, J.; An, Y.Y.; Feng, X.X.; Wang, L.J. Rhizospheric application with 5-aminolevulinic acid improves coloration and quality in 'Fuji' apples. Sci. Hortic-Amst. 2017, 224, 74-83. [CrossRef]

79. Maodzeka, A.; Wang, Q.; Chen, X.Y.; Hussain, N.; Wu, D.Z.; Jiang, L. Effects of 5-aminolevulinic Acid on the Bioactive Compounds and Seedling Growth of Oilseed Rape (Brassica napus L.). J. Plant Biol. 2019, 62, 181-194. [CrossRef]

80. Rebeiz, C.A.; Montazer-Zouhoor, A.; Hopen, H.J.; Wu, S.M. Photodynamic herbicides: 1. Concept and phenomenology. Enzym. Microb. Technol. 1984, 6, 390-396. [CrossRef]

81. Phung, T.-H.; Jung, S. Perturbed porphyrin biosynthesis contributes to differential herbicidal symptoms in photodynamically stressed rice (Oryza sativa) treated with 5-aminolevulinic acid and oxyfluorfen. Pestic. Biochem. Physiol. 2014, 116, 103-110. [CrossRef] [PubMed] 
82. Hiroyuki, K.; Tatsuru, M.; Shooichi, M. Action mechanism of diphenyl ether herbicides; Stimulation of 5-aminolevulinic acid-synthesizing system activities. Pestic. Biochem. Physiol. 1989, 33, 230-238.

83. Ling, X.; Wenfang, Z.; Basharat, A.; Faisal, I.; Jinwen, Z.; Weijun, Z. Synergism of herbicide toxicity by 5-aminolevulinic acid is related to physiological and ultra-structural disorders in crickweed (Malachium aquaticum L.). Pestic. Biochem. Physiol. 2015, 125, 53-61.

84. Koizumi, N.; Harada, Y.; Minamikawa, T.; Tanaka, H.; Otsuji, E.; Takamatsu, T. Recent advances in photodynamic diagnosis of gastric cancer using 5-aminolevulinic acid. World J. Gastroentero. 2016, 22, 1289-1296. [CrossRef] [PubMed]

85. Keiji, I. 5-Aminolevulinic acid-mediated photodynamic therapy for bladder cancer. Int. J. Urol. 2017, $24,97-101$.

86. Peiru, W.; Guolong, Z.; Linglin, Z.; Zhongxia, Z.; Lei, S.; Qingyu, Z.; Lude, Z.; Xiuli, W. 5-Aminolevulinic acid photodynamic therapy for early-stage lip squamous cell carcinoma. Photodiagn. Photodyn. Ther. 2021, 35, 102321.

87. Di Venosa, G.; Fukuda, H.; Batlle, A.; MacRobert, A.; Casas, A. Photodynamic therapy: Regulation of porphyrin synthesis and hydrolysis from ALA esters. J. Photochem. Photobiol. B Biol. 2006, 83, 129-136. [CrossRef]

88. Chi, Z.; Ting, G.; Jiajia, W.; Adriana, C.; Jack, J.J. Topical Application of 5-Aminolevulinic Acid Is Sufficient for Photodynamic Therapy on Vocal Folds. Laryngoscope 2018, 129, E80-E86.

89. Cappugi, P.; Campolmi, P.; Mavilia, L.; Prignano, F.; Rossi, R. Topical 5-aminolevulinic acid and photodynamic therapy in dermatology: A minireview. J. Chemother. 2002, 13, 494-502. [CrossRef]

90. Amit, K.J.; Chang Hyun, L.; Harvinder, S.G. 5-Aminolevulinic acid coated microneedles for photodynamic therapy of skin tumors. J. Control. Release 2016, 239, 72-81.

91. Wei, Z.; Xiao-Feng, S.; Chang-Liang, W.; Xin-Zhou, L.; Zhen, L.; Hai-Lu, X.; Zhong-Wei, L.; Rong-Tao, Z.; Jian-Ling, H.; Hong-Qing, T. Topical 5-aminolevulinic acid photodynamic therapy for intra anal-rectal warts. J. Dermatol. Treat. 2019, 31, $241-244$. 